\title{
Introducing Students to the Genre of Presentations for Professional Purposes
}

\author{
Slađana Živković, PhD \\ College of Applied Technical Sciences \& Faculty of Civil Engineering and Architecture, University of Niš, Serbia \\ Email: sladjanazivkovic.ni@gmail.com
}

\author{
Doi:10.5901/mjss.2015.v6n2s2p201
}

\begin{abstract}
The present paper discusses the genre of spoken presentations and provides information about how to improve communication skills and design a successful spoken presentation in order to function effectively in professional settings which is important in today's globalized and highly competitive world. It proposes ideas concerning the efficiency of presentations, and discusses the ways of arranging presentations in the EFL classroom. In the age of globalization and information technology, communication and presentation skills have become an important aspect of the workplace. So, graduates need to be proficient in spoken communication in order to function effectively in professional settings. Mastering the skills and genre of professional spoken presentations in today's highly competitive world is more important than ever. Teaching principles of spoken presentations at schools and faculties is an especially relevant curriculum segment and is done with the ultimate purpose of better communicating professional knowledge. By making students aware of basic points, types, characteristics and styles of professional spoken communication, the paper is to serve as a starting point in an attempt to make them expand and perfect their communication skills.
\end{abstract}

Keywords: genre, communication, spoken presentation

\section{Introduction}

This paper focuses on the genre of spoken presentations, and provides information about how to improve communication skills and design a successful spoken presentation in order to function effectively in professional settings which is important in today's globalized and highly competitive world.

College graduates are expected to have excellent communication skills, so, teaching principles of spoken presentations at faculties is an especially relevant curriculum segment. By making students aware of basic points, types, characteristics and styles of professional spoken communication, the paper is to serve as a starting point in an attempt to make them expand and perfect their communication skills. Webster (2002) argues that in order to create a safe classroom community of discourse, it is useful to offer learners explicit and systematic explanations of the way language functions in social contexts.

So, teaching students to design effective presentations implies training them insightful and well-trained thinking strategies that can produce clarity in communication without oversimplifying vocational issues. Improving the quality of presentation actually improves the quality of thought and vice versa. This is the ultimate result of a successful presentation.

\section{The Centrality of Spoken Presentation Skills}

To begin with, I would like to emphasize that globalization and the information technology revolution have reshaped workplace requirements. "Today's challenging economic situation means that it is no longer sufficient for a new graduate to have knowledge of an academic subject; increasingly it is necessary for students to gain those skills which will enhance their prospects of employment" (Fallows \& Steven, 2000). In today's world of competition employers are demanding graduates with excellent communication competence (Morgan, 1997; Alshare \& Hindi 2004). Therefore, with effective communication and presentation skills, experience and knowledge, students will gain a competitive advantage over others in the job market.

Therefore, making the course relevant to job or study needs is usually a good way to motivate the learner" (Ellis \& Johnson, 1994). Students' presentations in the classroom need to become "an important element in delivering positive learning experiences" (Alshare \& Hindi, 2004).

Introducing students to the genre of spoken presentations is an effective means of achieving a communicative goal 
(Swales, 1990). Bhatia (2008) explains genre as "language use in a conventionalised communicative setting in order to give expression to a specific set of communicative goals of a disciplinary or social institution, which give rise to stable structural forms by imposing constraints on the use of lexico-grammatical as well as discoursal resources".

Additionally, Gray (2010) argues that communication skills must be transferred from the classroom to the workplace. So, it is important to increase the number of spoken presentations to ensure that students are prepared for the professional environment after graduation.

\section{The Primary Goal of Foreign Language Teaching/Learning}

The primary goal of most foreign language learning, according to Littlewood (1981), is to develop the ability to use real and appropriate language to communicate and interact with others. The goal of foreign language teaching, consequently, is to extend the range of communicative situation in which the learners can perform with focus on meaning without being hindered by the attention he must pay to linguistic form (Littlewood, 1981).

Significantly, students should become clear about the goals of the course and their relevance to the program goals and the institutional contexts. It is also important to assess students' speaking skills based on their prior knowledge and experience and in direct relation to course activities. Keeping in mind these things, the first class begins with a course syllabus discussion activity.

Communication is more than merely an exchange of words between parties; it is a "...sociological encounter" (Halliday, 1978) and through exchange of meanings in the communication process, social reality is "created, maintained and modified" (Halliday, 1978). Communication task "involves learners in comprehending, manipulating, producing or interacting in the language" (Nunan, 1989).

Many professionals need to create spoken presentations "in one capacity or another over the course of their careers. Sometimes they will have to present new ideas or progress reports to their colleagues and bosses, or sometimes they will share the findings of their latest scientific inquiries with their peers" (Platow, 2002).

Moreover, exposing students to the genre of spoken presentations can be an effective method which motivates students to communicate, and can impart lifelong skill that extends beyond the academic context that is by strengthening the ability of students to transfer and apply their academic communication skills to the outside world.

\section{Bridging the Gap between Language Study and Language Use}

"New work skills are emerging as crucial for success in the $21^{\text {st }}$ century. These include skills of critical analysis, evaluation, experimentation, collaboration, communication, abstraction, system thinking, and persuasion" (Reich, 1991). Every professional is involved in some aspect of communication which usually involves gathering, analyzing, and distributing of scientific and/or technical information efficiently and accurately for specific audiences. Among the many advantages of oral presentations are: "bridging the gap between language study and language use; using the four language skills in a naturally integrated way; helping students to collect, inquire, organize and construct information; enhancing teamwork; helping students become active and autonomous learners" (King, 2002).

So, the aim is for the students to learn the structure of various kinds of communications and the appropriate style of speech. First, they are explained that learning the principles of spoken presentations is done with the ultimate purpose of better communicating professional knowledge to other professionals.

Special attention is paid for the students to understand that professional presentation communicates specific information about a specific subject to a specific audience for a specific purpose. Generally speaking, a presentation often focuses on resolving some problem or delivery of information. The purpose of a professional presentation may be to inform and/or persuade the audience that the speaker's method of resolving a problem is effective and efficient. The achievement of the preset purpose proves the validity of the presentation.

\section{Spoken Presentations - General Characteristics}

Spoken presentations are considered an integral part of almost every professional environment, as professionals may need to communicate with other professionals "by giving presentations in seminars, conferences and the workplace (King, 2002; Freeman, 2003). They demonstrate one of the most successful way "to get the student's attention, encourage curiosity, create challenges" (Hutchinson \& Waters, 1987) and master the situation.

One specially relevant part of foreign language instruction curriculum at faculties refers to the principles of spoken presentation skills for professional needs (Živković, 2011, 2014). The importance of these skills lies in the fact that they 
have a completely practical purpose and are directly related with the real future needs of the students. All decisions as to content (Wardrope \& Bayless, 1994) and method are based on the learner's reason for learning (Dudley-Evans \& St. John, 1998; Hutchinson \& Waters, 1987).

Besides, it is important to note that the study of presentation techniques is a chance for students to gain insight into knowledge and skills that make a good lecturer.

"The introduction of oral presentations to EFL classrooms provides a rewarding and stimulating experience both for teachers in developing facilitating skills and for students in training themselves to have confident presentations in public" (King, 2002). An oral presentation is one of the most important oral communication skills that entry level job candidates should possess (Campbell et al, 2001).

In addition, it is important to mention that the mastery of the subject topic and the good will to interact with others will allow them to actually enjoy sharing their knowledge in a constructive way, both for their audience and themselves with plan and organizational structure (Živković, 2013, 2014).

\section{Objectives of the Study}

Presentations for professional purposes are becoming important part of language teaching, especially in the university environment. So, students need to be able to:

- $\quad$ prepare and organize material for effective presentations for professional purposes

- demonstrate the ability to deliver well-organized oral presentations

- deliver professional presentations

- improve communication skills

- learn the structure of the appropriate style of speech

- utilize visual aids effectively

- develop effective organizational strategies

- understand that a professional presentation communicates specific information about a specific subject to a specific audience for a specific purpose

- enhance self-confidence

The ultimate result of a successful presentation is communicating professional knowledge to other professionals. This innovative framework provides a holistic approach in assessing a student's performance based on the content and the delivery of their presentation (Carroll, 2006).

\section{Conducting a Spoken Presentation}

Since spoken presentations involve multi-skills, carefully planned and constructed guidelines and instruction (Martin, 1990) will help develop students' receptiveness to spoken presentations (King, 2002). If properly guided and organized, spoken presentations provide a learning experience and teach lifelong skills that will be beneficial to students in all school subjects, and later in their careers (Melony \& Thompson, 1980).

Giving instructional objectives and style (Burke, 2011) can increase students engagement in the classroom, and enhance their performance with the ultimate goal of being a successful communicator in the future professional surrounding (Živković, 2014). So, it is needed to consider a number of factors when conducting a spoken presentation, and to develop "effective learning strategies for both language and communication skills" (Sweeney, 1997).

- Shape the presentation

The presentation can have the following aims: to inform the audience about a topic, to persuade them to accept your argument, to motivate them to listen and agree with your attitudes, and finally, to inspire the audience with a powerful presentation. Depending on these, the structure and shape of the presentation will vary significantly.

The organization will depend on the overall purpose of the talk, but basically it may be of the following kinds (Živković, 2011):

- classifications - organizing information into groups that share common characteristics,

- partition - organizing information into sections and sub-sections,

- cause and effect - describing and persuading by means of identifying casual relationships,

- $\quad$ problem and solution - organizing material in response to a dilemma,

- experimentation - organizing the information given, the purpose, aim, materials, procedures, results and discussion. 


\section{A Model for Structuring a Spoken Presentation}

Students need to learn the structure of various kinds of communication and the appropriate style of speech. Here is a model to help students structure their presentations.

A) Introduction

What is significant is to prepare a suitable introduction and establish contact with the audience. The introduction contains: greeting the audience, introducing yourself and your company, identifying the topic, and explaining the purpose of the talk. It is necessary to get and keep the audience's attention and interest by connecting their needs and knowledge to the topic of the speech.

- Greeting your audience

The first thing to be done is to greet the audience. Let's take a look at some samples:

Good morning ladies and gentlemen. Thank you for coming...

Good afternoon everyone. I'm very pleased to be with you today...

Good afternoon everyone. It's a great pleasure for me to be here with you today...

Good evening esteemed guests. Thank you very much for coming today...

- Introducing yourself and your company

Then, introduce yourself, and say a few words about your job and your company. Remember, the way you introduce yourself provides people with a first impression of you. Here are some expressions to do this:

l'd like to introduce myself...

My name is... I'm manager of...

Let me introduce myself... I'm a representative of...at (company name)...

- Introducing the topic

Tell the audience what you are going to speak about. Begin with a clear and appropriate topic. But remember, it depends on the needs of the learners in relation to their future jobs (Ellis \& Johnson, 1994).

"Learners are free to choose any topic they prefer in three categories: event-or goal-oriented; student-initiated; and in-depth topic studies, in order to enhance their self-expression and creativity" (King, 2002).

You can introduce the topic by saying:

The subject of my talk will be...

My talk is concerned with...

The subject of my presentation is...

What l'd like to present to you today is...

Today's topic is...

In today's presentation l'd like to explain to you ...

In today's presentation I'm going to give you an overview of ...

In today's presentation I'm planning to explain ...

I'm going to talk about...

- Explaining the purpose of the talk

Familiarize the audience with the purpose/objective/aim, content, and the structure of the presentation. "Knowing the content of the functional areas of business is important, but to give life to those ideas - in meetings or in solo presentations - demands an effective oral presentation" (Murphy \& Hildebrandt, 1990).

The main purpose of the talk refers to "whether the audience accurately perceives what the author has in mind" (Gopen \& Swan, 1990).

Here are some phrases for stating the purpose of your presentation:

The purpose of today's presentation is...

The purpose/objective/aim today is .....

The subject of my presentation is ...

The purpose of my talk is ...

- B) The body of the presentation

You should outline your presentation to give the audience a clear overview of what they can expect. The body 
should be presented in a logical order for the audience to follow. It will be useful to divide the content into sections (and sub-sections), so, the audience will know where they are at any time during your talk. One of the good ideas is to pause between sections of your talk.

- $\quad$ Moving to the point

My presentation consists of three parts...

This talk is divided into three main sections.

In the first part (section) I will concentrate on...

The second part will focus on...

Finally, in the third part, l'll talk about....

In the last part l'll offer some solutions...

\section{- Giving examples}

For example...

Now let's take an example...

A good example of this is...

Let me give you an example...

To illustrate this point, I will give some example...

As an illustration...

- Introducing visual aids

We live in the age of visual communication, so, visual aids can effectively support oral presentations (Doff, 1988; Dudley-Evans \& Maggie, 2002). There are many advantages in using visual aids during the presentation. They are used in order to create a powerful effect, keep audiences' attention. They are also used to illustrate points easier to understand in visual form and, overall, to maximize the effectiveness of the presentation.

They can be: slides, handouts, flipcharts, overhead projector, whiteboards, graphs, charts, maps, photos, drawings, images, posters, videotapes. Videotaping student presentations is an effective way of enhancing student presentation skills (Baker \& Thompson, 2004).

Besides, by using visual aids, presentations are more persuasive, more understandable, more professional, more memorable, and more interesting.

What is worth noting is that visual aids are used to support the presentation, not to dominate it. Otherwise, the disadvantage of overusing visual aids is that the attention of the audience will be divided and students may stand aside and have visual aids take their place (King, 2002).

The following phrases can be used:

This graph shows you...

Take a look at this table...

If you look at this diagram, you will see...

This chart illustrates the figures...

This graph gives you...

This chart clearly shows...

If you look at the screen, you'll see ...

This diagram/chart/slide clearly shows ...

\section{C) Conclusion}

Conclusion of your talk should include three parts: a brief summary of what you have shown in your speech, thanking the audience for listening, and an invitation to ask questions, make comments or open a discussion. This may take the form of a recapitulation of the main points.

- $\quad$ Summarizing

At the end of your presentation, you should summarize your talk in order to remind the audience of the key points. Here are some expressions:

Now, l'd like to summarise...

Well, that brings us to the end of our talk.

Now, just to summarise...

Let's quickly look at the main points again. 


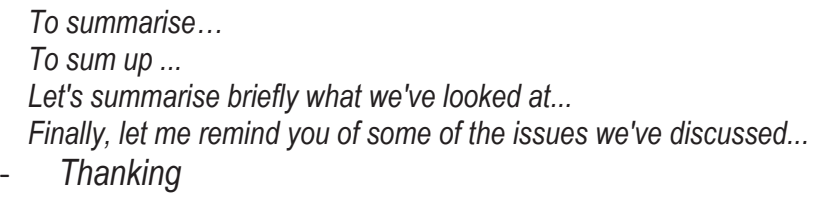

l'd like to thank you (all) for your attention. Thank you all for your patience. Have a good day.

Thank you for your attention and interest in this discussion.

Thank you all for being here today and patiently listening to what I said.

l'd like to finish by thanking you (all) for your attention.

- $\quad$ Inviting questions

If you have any questions, please feel free to ask them. Would you like to ask any questions?

If you have any questions, please ask them now.

Does anyone have any questions?

If anyone has any questions, l'll be pleased to answer them.

If you have any questions, I'll do my best to answer them.

As a summary to all mentioned above, it is important to point out that spoken presentations need to occupy a significant part of language teaching classes. By their nature they can be taught only as an interactive kind of lecturing. Through practice work, students reproduce the knowledge lectured through their own examples. The aim of such classes is practical and concrete. It is tailored according to the needs of specific professions and allows students to present the acquired academic knowledge in both academic and professional environment.

\section{Conclusion}

This paper has discussed relevant practical points related to the genre of spoken presentations in the EFL classroom.

Spoken presentations are an integral part of almost every professional environment, as professionals need to communicate with other professionals in seminars, conferences, business meetings, congresses. Hereby, students need a thorough in-depth instruction and practice in spoken communication.

So, students need to learn the structure of various kinds of communications and the appropriate style of speech. First, they are explained that learning the principles of spoken presentations in English is done with the ultimate purpose of better communicating professional knowledge. Special attention is paid for students to understand that professional presentation communicates specific information about a specific subject to a specific audience for a specific purpose. The audience element is crucial for the successful presentation. The presenter needs to make a precise judgment about who they talk to, and according to that adapt their presentation to the audience's needs, expectations, levels of understanding, background. It means, the presenter has to identify the audience as precisely as possible (experts, technicians, executives, nonspecialists). Different audiences require different amount and depths of information.

It is important to note that in this era of increasing internationalization, opportunities for students to study or work abroad are growing steadily, and being able to speak to a group with confidence and ease is an essential skill (Webster, 2002). With the experience of spoken presentations, students (future specialists) can forge ahead with more selfawareness, speaking skills and strategies required to create other similar presentations.

\section{References}

Alshare, K. \& Hindi, N.M. (2004). The Importance of Presentation Skills in the Classroom: Students and Instructors Perspectives. Journal of Computing Sciences in Colleges, 19 (4), 6-15.

Baker, W. H. \& Thompson, M. P. (2004). Teaching Presentation Skills. Business Communication Quarterly, 67(2), $216-219$.

Bhatia, Vijay K., (2008): Genre Analysis, ESP and ProfessionalPractice, English for Specific Purposes, 27, [161--74]

Burke, B. M. (2011). Rituals and beliefs ingrained in world language pedagogy: Defining deep structure and conventional wisdom. Journal of Language Teaching and Research, 2(1), 1-12.

Campbell, K., Mothersbaugh, D., Brammer, C., \& Taylor, T. (2001). Peer versus self assessment of oral business presentation performance. Business Communication Quarterly 64(3), 23-42.

Carrol, C. (2006). Enhancing Reflective Learning through Role-Plays: The Use of an Effective Sales Presentation Evaluation Form in 
Student Role-Plays. Marketing Education Review, 16 (1), 9-13.

Doff, A. (1988). Teach English - A Training Course for Teachers. Cambridge, England: Cambridge University Press.

Dudley-Evans, T., \& St. John, M. J. (1998). Developments in English for Specific Purposes: A Multidisciplinary Approach. Cambridge: Cambridge University Press.

Dudley-Evans T. and J. Maggie (2002). Development in ESP: A Multi-disciplinary Approach. New York: Cambridge University Press.

Ellis, M. and C. Johnson (1994). Teaching Business English. Hong Kong: Oxford University Press.

Freeman, J. (2003). The Science of Conversation: Training in Dialogue for NNS in Engineering. IEEE Transactions of Professional Communication, 46 (3), 157-167.

Gopen, G. D. \& Swan J. A. (1990). The Science of Scientific Writing. American Scientist, Volume 78, 550-558.

Gray, F. E. (2010). Specific Oral Communication Skills Desired in New Accountancy Graduates. Business Communication Quarterly, 73(1), 40-67.

Fallows, S. \& Steven, C. (2000). Building Employability Skills into the Higher Education Curriculum: A University-wide Initiative. Education \& Training, 42(2), 75-83.

Halliday, M.K., (1978). Language as social semiotic. London: Edward Arnold.

Hutchinson, T. \& Waters, A. (1987). English for specific purposes. Cambridge: CUP.

King, J. (2002). Preparing EFL learners for oral presentations preparing. Dong Hwa Journal of Humanistic Studies, 4, 401-418.

Littlewood, W. (1981). Communicative Language Teaching: An Introduction. Cambridge: Cambridge University Press.

Martin, C. L. (1990). Enhancing the Effectiveness of Student Oral Presentations. Marketing Education Review, 1(1), 56-60.

Meloni, C. \& Thompson, S. (1980). Oral reports in the intermediate ESL classroom. TESOL Quarterly, 14 (4), 503-510.

Morgan, G. J. (1997). Communication Skills Required by Accounting Graduates: Practitioner and Academic Perceptions. Accounting Education, 6(2), 93-107.

Murphy, H. A. \& Hildebrandt, H. W. (1990). Effective business communications. UK: McGraw-Hill Ryerson, Ltd.

Nunan, D. (1989). Designing Tasks for the Communicative Classroom. Cambridge: Cambridge University Press.

Platow, J. M. (2002). Giving professional presentations in the behavioral sciences and related fields. New York: Taylor \& Francis Books, Inc.

Reich, R. 1991. The work of nations: Preparing ourselves for 21st century capitalism. New York: Knopf.

Swales, J.M. (1990) Genre Analysis: English in academic and research settings. Cambridge: Cambridge University Press.

Sweeney, S. (1997). English for Business Communication. Cambridge: Cambridge University Press.

Wardrope, W. J., \& Bayless, M. L. (1994). Oral Communication Skills Instruction in Business Schools. Journal of Education for Business, 69(3), 132-136.

Webster, F. (2002). A genre approach to oral presentations. Internet TESL Journal, 8(7).

Živković, S. (2011). Modernization of English as Foreign Language Studies in University Education, in University Education in Transition, Transition in University Education - Modern and Universal, Belgrade, pp. 213-223.

Živković, S. (2013). To Modernize or not to Modernize - There is no Question. Academic Journal of Interdisciplinary Studies. MCSER Publishing: Rome-Italy.

Živković, S. (2014). The Importance of Oral Presentations for University Students, Mediterranean Journal of Social Sciences, Vol. 5, No. 19, 2014, Rome, Italy.

Živković, S. (2014). Teaching Students How to Master Spoken Presentation Skills, $4^{\text {th }}$ International Conference on Human and Social Sciences ICHSS, Faculty of Philosophy Nikšić, University of Montenegro and MCSER-Rome, Italy, May 31-June 1, Budva, Montenegro.

Živković, S. (2014). Constructivism - An Emerging Trend in ESP Teaching and Learning. International Conference Language, Literature and Culture in Education. Nitra, Slovakia.

Živković, S. (2014). Teaching Students how to master Spoken Presentation Skills, Journal of Educational and Social Research, Vol. 4, No 4, Rome, Italy. 
